\title{
Rapid measurement of radical oxygen species in biological fluids may help to diagnose infection
}

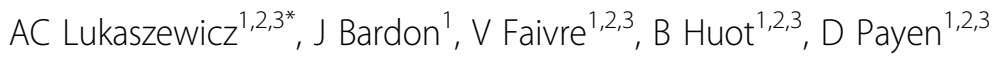 \\ From ESICM LIVES 2015 \\ Berlin, Germany. 3-7 October 2015
}

\section{Introduction}

Recently, we showed the interest of instantaneous production of radical oxygen species (ROS) for diagnosis of meningitis ([1]). Polymorphonuclear neutrophils (PMN) are a major source of ROS through the activation of protein kinase $\mathrm{C}$ and NADPH oxidase pathway, which may differ according to stimuli.

\section{Objectives}

To test if ROS measurements related to infection is different from other cause of ROS production in: pleural (PIF), peritoneal (PerF) fluids and bronchoalveolar lavage (BAL).

\section{Methods}

Monocentric study in ICU patients with systemic inflammatory response syndrome and suspicion of infection. PIF, PerF or BAL sampled for measurement of ROS by luminescence (luminol, basal condition or stimulation by phorbol 12-myriaste 13-acetate (PMA, PKC activator)) ([1]). Non parametric tests, $\mathrm{p}<0.05$. Results are expressed in area under the curve of luminescence (AUC), median (25-75th percentiles).

Definition of infection: microbiological positivity in BAL culture $\left(\geq 10^{4} \mathrm{UFC} / \mathrm{ml}\right)$, in PerF or PlF, or number of PMNs $\geq 250 / \mathrm{mm}^{3}$ in PerL

\section{Results}

58 patients, SAPSII 43 (34-51), temperature $37.5^{\circ} \mathrm{C}$ (36.6-38), leukocytes $13800 / \mathrm{mm}^{3}$ (11175-23800). 17 PerF (35\% infected), 28 PIF (29\%infected), 20 BAL (35\% infected). Culture were positive for Stenotrophomonas maltophilia in PerF and Pseudomonas aeruginosa in PIF and BAL.

\footnotetext{
${ }^{1}$ Hopital Lariboisiere, Assistance Publique Hôpitaux de Paris, Département d'Anesthésie Réanimation SMUR, Paris, France

Full list of author information is available at the end of the article
}

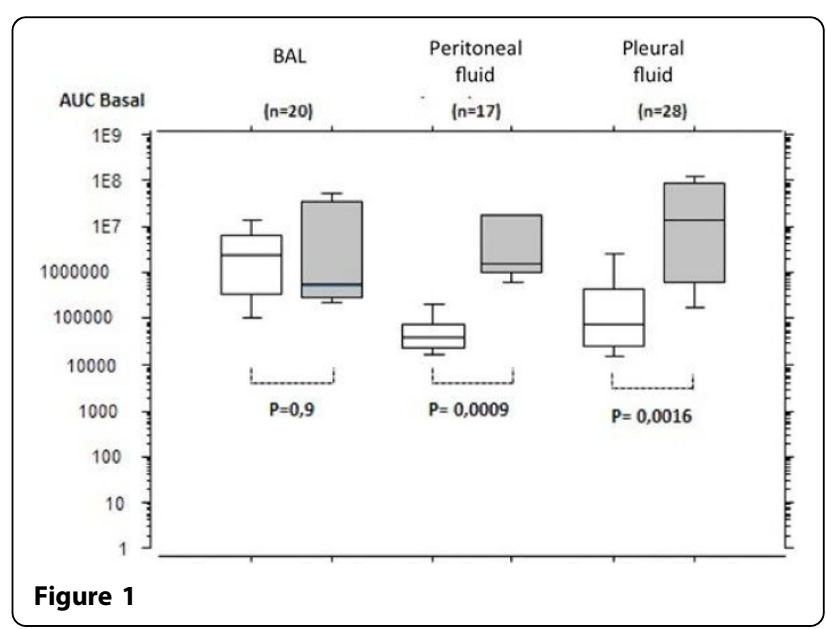

AUC ROS luminescence was elevated for basal (Figure) and PMA stimulated condition when infection was present (grey boxes) in PerF ( $p=0.0009, p=0.001$ respectively) and in PIF ( $\mathrm{p}=0.0016, \mathrm{p}=0.0019$ ) compared to negative culture (white boxes), but not in BAL. If ROS production was reported to the number of PMNs, there was no difference according to infection.

\section{Conclusions}

Instantaneous production of ROS was significantly increased when infection was present in PerF and PlF but not in BAL. These results questioned the validity of BAL for characterization of inflammation ([2]). This test is simple to diagnose the presence of infection and requires a validation in a larger cohort.

\section{GRANT ACKNOWLEDGMENT}

Ministère de l'Enseignement Supérieur et de la Recherche. Patent WO 2012/014156.

\section{SpringerOpen $^{\odot}$}

(c) 2015 Lukaszewicz et al.; This is an Open Access article distributed under the terms of the Creative Commons Attribution License (http://creativecommons.org/licenses/by/4.0), which permits unrestricted use, distribution, and reproduction in any medium, provided the original work is properly cited. 


\section{Authors' details}

${ }^{1}$ Hopital Lariboisiere, Assistance Publique Hôpitaux de Paris, Département d'Anesthésie Réanimation SMUR, Paris, France. ${ }^{2}$ Université Paris Diderot,

Sorbonne Paris Cité, Paris, France. ${ }^{3}$ INSERM UMR 1160, Paris, France.

Published: 1 October 2015

\section{References}

1. Lukaszewicz AC, Gontier G, Faivre V, Ouanounou I, Payen D: Elevated production of radical oxygen species by polymorphonuclear neutrophils in cerebrospinal fluid infection. Ann Intensive Care 2012, 2:10.

2. Chollet-Martin S, Gatecel C, Kermarrec N, Gougerot-Pocidalo MA, Payen DM: Alveolar neutrophil functions and cytokine levels in patients with the adult respiratory distress syndrome during nitric oxide inhalation. AJRCCM 1996, 153:985-90.

doi:10.1186/2197-425X-3-S1-A645

Cite this article as: Lukaszewicz et al:: Rapid measurement of radical oxygen species in biological fluids may help to diagnose infection. Intensive Care Medicine Experimental 2015 3(Suppl 1):A645.

\section{Submit your manuscript to a SpringerOpen ${ }^{\mathcal{O}}$ journal and benefit from:}

- Convenient online submission

- Rigorous peer review

- Immediate publication on acceptance

- Open access: articles freely available online

- High visibility within the field

- Retaining the copyright to your article 